\title{
A Combination Fungicide for the Management of Sheath Blight, Sheath Rot and Stem Rot Diseases of Paddy
}

\author{
D. Pramesh ${ }^{1,2} *$, Saddamhusen Alase ${ }^{1,2}$, K.M. Muniraju ${ }^{1,2}$ and M. Kirana Kumara ${ }^{1,2}$ \\ ${ }^{1}$ All India Coordinated Rice Improvement Programme, Agricultural Research Station, \\ Gangavathi-583 227, Karnataka, India \\ ${ }^{2}$ Department of Plant Pathology, University of Agricultural Sciences, \\ Raichur-584104, Karnataka, India \\ *Corresponding author
}

\section{A B S T R A C T}

\begin{tabular}{|c|}
\hline Keywords \\
\hline $\begin{array}{l}\text { Sheath blight, } \\
\text { Sheath rot, Stem } \\
\text { rot, TAQAT } 75 \\
\text { WP, PDI. }\end{array}$ \\
\hline Article Info \\
\hline $\begin{array}{l}\text { Accepted: } \\
\text { 10 July } 2017 \\
\text { Available Online: } \\
\text { 10 September } 2017\end{array}$ \\
\hline
\end{tabular}

A new combination fungicide TAQAT 75\% WP (Captan 70\% + Hexaconazole 5\%) was tested in different doses against rice sheath blight (ShB), sheath rot (ShR) and stem rot (StR) diseases under field conditions during Kharif 2013 and Rabi 2013-14. The combination fungicide TAQAT 75\% WP (Captan 70\% + Hexaconazole 5\%) @ $750 \mathrm{~g} / \mathrm{ha}$ was found effective against $\mathrm{ShB}$, ShR and StR diseases recording least percent disease index (PDI) of 13.33, 14.44 and 13.7 respectively during Kharif 2013. Similar trend was observed during the Rabi 2013-14 where test fungicide TAQAT 75\% WP recorded least PDI of $14.11,14.16$ and 17.49 against ShB, ShR and StR diseases respectively. Compared to TAQAT 75\% WP, other test fungicides such as Captan 50\% WP and Hexaconazole 5\% SC at different doses recorded highest PDI against ShB, ShR and StR in both Kharif 2013 and Rabi 2013-2014. Significant increase in grain yield $(67.25 \mathrm{q} / \mathrm{h})$ was observed in the plots treated with test chemical TAQAT 75\% WP $750 \mathrm{~g} / \mathrm{ha}$ in Kharif 2013 and 64.35 q/ha during Rabi 2013-14, whereas, other fungicidal treatments recorded the yield in the range of 44.52-61.25 q/h (Kharif 2013) and 41.32-58.50 (Rabi 2013-14).

\section{Introduction}

Rice (Oryza sativa L.) is the world's most important crop and a primary source of food for more than half of the world's population. More than $90 \%$ of the world's rice is grown and consumed in Asia where $60 \%$ of the earth's people live (Kole, 2006). Ever growing population in India is further demanding more rice production and productivity. Under field condition, the productivity of rice is affected by many biotic and abiotic factors. Among the different biotic constraints, diseases caused by fungal pathogens such as sheath blight, sheath rot and stem rot cause significant damage in irrigated rice (Jackson et al., 1977; Bonman et al., 1991; Kindo and Tiwar, 2015).

Rice sheath blight caused by Rhizoctonia solani Kuhn (Teleomorph: Thanatephorus cucumeris (Frank) Donk), is a destructive disease worldwide that causes significant yield loss and quality degradation (Lee and Rush, 1983; Ou, 1985; Teng et al., 1990; Savary et al., 2000; Savary et al., 2006). In 
India, a modest estimation of losses due to the sheath blight disease alone has been up to $54.3 \%$ (Rajan, 1987; Roy, 1993). The disease is particularly important in intensive rice production systems (Savary and Mew, 1996). Yield losses of 5-10\% have been estimated for tropical lowland rice in Asia (Savary et al., 2000).

Sheath rot caused by Sarocladium oryzae (Sawada) Games and Hawksworth has become a serious problem in most of the rice growing area of the country was first reported in 1973 (Agnihothrudu, 1973). Sheath rot has gained the status as a major disease of rice (Reddy and Gosh 1985) and yield losses varies from 9.6 to $85 \%$ depending on the weather conditions during the crop growthperiod (Phookan and Hazarika, 1992). Yield loss up to $85 \%$ was also reported in most ricegrowing regions of the world (Naeimi, et al., 2003).

Stem rot of rice caused by Sclerotium oryzae is becoming a serious problem of rice cultivation in the Indian subcontinent (Singh et al., 2002). The causal agent was first described from Italy in the sclerotial form and was named $S$. oryzae Catt. (Cattaneo, 1876). Singh and Devi (1999) reported the occurrence of the stem rot of rice in Manipur in almost all the varieties cultivated. In Karnataka, this disease occurred in epidemic form during 2012-13 and yield loss up to 30\% was reported on paddy cultivar BPT5204 in North eastern part of Karnataka (Pramesh et al., 2014). This disease was also reported to be the major constraint for paddy cultivation in Andra Pradesh state in recent years (Gopika et al., 2016).

Fungicide based management of sheath blight disease is successful at filed level in majority of the cases (Kandhari et al., 2003; Kandhari and Gupta, 2003; Groth and Bond 2006; Bhuvaneshwari and Raju, 2012; Kumar et al., 2013). For sheath rot disease management, several fungicides such as Hexaconazole 5 SC, Tebuconazole 250 EC and Carbendazim $50 \%$ WP were shown to be highly effective in reducing the sheath rot severity under field condition (Venkateswarlu and Venkateswarlu, 2004; Karamkar et al., 1992; Vidhyasekaran and Lewin, 1987; Anonymus, 2009; Kindo and Tiwari, 2015).

Several cultural and biological methods have been reported for stem rot disease management under field condition (Cintas and Webster, 2001; Sakthivel and Gnanamanickam, 1987; Yang et al., 2009; Gopika et al., 2016). Several fungicides such as Benomyl, Edifenphos, Thiophanate Methyl, Propiconozole have been found to be effective in reducing stem rot disease severity under field condition (Singh et al., 2002; Kumar et al., 2003; Gopika et al., 2016).

Fungicides have been used successfully to control fungal diseases of rice. Research findings suggest the chance of a pathogen developing resistance to a particular chemical increases with regular use over a period of time (Brent and Hollomon 1998; Zhang et al., 2009). The alternatives are to develop a new chemical (fungicide) class that has no cross resistance to the chemical to which the pathogen developed resistance originally or to develop a combination products with different mode of action on fungal physiology. In this view, present study was undertaken to appraise the field efficacy of TAQAT 75\% WP (Captan 70\% + Hexaconazole 5\%), a combination fungicide against sheath blight, sheath rot and stem rot diseases of paddy under field conditions.

\section{Materials and Methods}

\section{Layout, fungicides and crop establishment}

A field experiment was conducted to evaluate the bio-efficacy of new fungicide combination against sheath blight, sheath rot and stem rot 
diseases at the experimental fields of Agricultural Research Station, Gangavathi, Karnataka $\left(5.4319^{\circ} \mathrm{N}, 76.5315^{\circ} \mathrm{E}\right)$ during Kharif 2013 and Rabi 2013-14. A popular rice variety BPT5204 which is susceptible to sheath blight, sheath rot and stem rot diseases was used for the study. For Kharif 2013 experiment, seeds were sown in the month of July and planted in August. For Rabi 2013-14 experiment, seeds were sown in the month of November and planted in the month of December. Before sowing, healthy seeds were water soaked overnight and incubated in the gunny bags for better sprouting in the nursery. The land was prepared by puddling method by applying one ploughing followed by two ploughing after one week. The experiment was laid out in randomized complete block design (RCBD) with a plot size of $5 \times 4 \mathrm{~m}$ each for all treatments. Seedlings of 30 days old were planted in trail plots at $20 \times 10 \mathrm{~cm}$ spacing. All standard agronomic practices were followed except using higher nitrogenous (200 kg ha-1) and lower pottasic (50 kg ha-1) fertilizer dose than the normal dose $\left(\mathrm{N}_{2}: \mathrm{P}_{2} \mathrm{O}_{5}: \mathrm{K}_{2} \mathrm{O}:: 150: 75: 75\right)$.

The RCBD experiment comprises eight treatments with three replications each. A new combination formulations viz., Captan 70\%+ Hexaconazole 5\% (TAQAT 75 WP) was tested in two doses $(500 \mathrm{~g} / \mathrm{ha}$ and $750 \mathrm{~g} / \mathrm{ha})$ along Captan 50\% WP (@ $700 \mathrm{~g} / \mathrm{ha}$ and 1050 g/ha) and Hexaconazole 5 \% SC (@ 500, 750 and $1000 \mathrm{ml} / \mathrm{ha}$ ). Bio-efficacy was evaluated after spraying all the test chemicals twice at 20 days interval starting from the initiation of the disease.

\section{Artificial inoculation}

Sheath blight disease was artificially inoculated to all experimental treatments after 45 days of planting following the 'mycelium with typha grass' method described previously (Bhaktavatsalam et al., 1978).
Sheath rot and stem rot diseases were evaluated based on natural disease incidence.

\section{Disease assessment and statistical analysis}

Fifteen days after the fungicide application disease assessment was carried out. For measuring sheath blight and sheath rot diseases, 0-9 disease rating scale developed by International Rice Research Institute (IRRI. 1996) was used. For stem rot disease, disease severity was measured based on 0-9 scale (SES, IRRI, 1980). Further, the scored data was converted into per cent disease index (PDI) using formula given below. The data on the yield were recorded by marking $3 \times 2 \mathrm{~m}$ section within each plot using a wire frame as described by (Seebold et al., 2004) and tillers within the frame were cut and harvested in order to determine the yield. Subsequently, the data on disease severity and yield parameters were subjected to appropriate statistical analysis.

PDI $=[$ (Sum of the scores) $/$ (Number of Observation $X$ Highest Number in Rating Scale)] x 100

\section{Results and Discussion}

\section{Sheath blight}

In recent time, combination fungicides are widely used in disease management under field condition because of their curative action, broad range and lower dosage compared to their solo formulations. In rice, efficacy of such combi-products in managing many fungal diseases has been reported (Bag and Saha, 2009; Bhuvaneshwari and Raju, 2012; Kumar and Veerabhadraswamy, 2014; Pramesh et al., 2016b). In the present study, field experiment revealed that the treatment TAQAT 75\% WP (Captan 70\% + Hexaconazole 5\%) @ 750 g/ha recorded lowest PDI of sheath blight in Kharif 2013 
(13.33) and Rabi 2013-14 14.11) compared to other treatments (Table 1). There was a significant difference among the treatments with respect to PDI of sheath blight and all treatments recorded significantly lower PDI compare to untreated control in both the seasons. This finding is in full agreement with the previous reports, where combination fungicides Trifloxystrobin 25\% + Tebuconazole 50\% (Nativo 75 WG) @ 0.4 g/l performed better in reducing the sheath blight severity (Bag and Saha, 2009; Pramesh et al., 2016a). Similarly, Bhuvaneshwari and Raju (2012) reported the better efficacy of a combination fungicide azoxystrobin $18.2 \%+$ difenoconazole $11.4 \%$ SC against sheath blight disease.

\section{Sheath rot}

For sheath rot disease management, several previous reports suggested the efficacy of solo fungicides such as Hexaconazole $5 \mathrm{SC}$, Tebuconazole $250 \mathrm{EC}$ and Carbendazim 50\% WP in reducing the sheath rot severity under field condition (Venkateswarlu and Venkateswarlu, 2004; Karamkar et al., 1992; Vidhyasekaran and Lewin 1987; Anonymus, 2009; Kindo and Tiwari, 2015). In our experiment, test fungicide TAQAT 75\% WP (Captan 70\% + Hexaconazole 5\%) @ 750 $\mathrm{g} / \mathrm{ha}$ recorded lowest PDI of sheath rot in Kharif 2013 (14.4) and Rabi 2013-14 (14.16) compared to other treatments (Table 2) (Figs. 1 and 2).

Table.1 Effect of TAQAT 75\% WP (Captan 70\% + Hexaconazole 5\%) on sheath blight disease of rice

\begin{tabular}{|c|c|c|c|c|}
\hline \multirow[t]{2}{*}{ SI No. } & \multirow[t]{2}{*}{ Treatments } & \multirow[t]{2}{*}{ Dose/l } & \multicolumn{2}{|c|}{ Disease Severity (PDI) } \\
\hline & & & Kharif 2013 & Rabi 2013-14 \\
\hline $\mathrm{T} 1$ & TAQAT 75\% WP & $500 \mathrm{~g}$ & 22.96 & 24.67 \\
\hline & $($ Captan $70 \%+$ Hexaconazole $5 \%)$ & & $(28.59)$ & $(29.73)$ \\
\hline T 2 & $\begin{array}{l}\text { TAQAT } 75 \% \text { WP } \\
(\text { Captan } 70 \%+\text { Hexaconazole } 5 \%)\end{array}$ & $750 \mathrm{~g}$ & $\begin{array}{c}13.33 \\
(21.39)\end{array}$ & $\begin{array}{c}14.11 \\
(22.06)\end{array}$ \\
\hline T 3 & Captan 50\% WP & $700 \mathrm{~g}$ & $\begin{array}{c}34.07 \\
(35.67)\end{array}$ & $\begin{array}{c}27.93 \\
(27.20)\end{array}$ \\
\hline $\mathrm{T} 4$ & Captan 50\% WP & $1050 \mathrm{~g}$ & $\begin{array}{c}37.77 \\
(37.88)\end{array}$ & $\begin{array}{c}25.37 \\
(30.20)\end{array}$ \\
\hline T5 & Hexaconazole 5\% SC & $500 \mathrm{ml}$ & $\begin{array}{c}31.48 \\
(34.08)\end{array}$ & $\begin{array}{c}31.93 \\
(34.39)\end{array}$ \\
\hline T6 & Hexaconazole 5\% SC & $750 \mathrm{ml}$ & $\begin{array}{c}31.10 \\
(33.90)\end{array}$ & $\begin{array}{c}28.74 \\
(30.46)\end{array}$ \\
\hline T7 & Hexaconazole 5\% SC & $1000 \mathrm{ml}$ & $\begin{array}{c}30.74 \\
(33.65)\end{array}$ & $\begin{array}{c}24.07 \\
(29.33)\end{array}$ \\
\hline T8 & Control & -- & $\begin{array}{c}50.37 \\
(45.17)\end{array}$ & $\begin{array}{c}47.37 \\
(43.39)\end{array}$ \\
\hline & Co-efficient of Va & nce (CV) & 13.43 & 12.68 \\
\hline & Critical Diff & nce (CD) & 3.68 & 2.9 \\
\hline
\end{tabular}

Figures in the parentheses represent arcsine transformed values 
Table.2 Effect of TAQAT 75\% WP (Captan 70\% + Hexaconazole 5\%) on sheath rot disease of rice

\section{Disease Severity (PDI)}

\begin{tabular}{|c|c|c|c|c|c|c|}
\hline \multirow{2}{*}{$\begin{array}{c}\text { Sl } \\
\text { No }\end{array}$} & \multirow{2}{*}{ Treatments } & \multirow{2}{*}{ Dose/l } & \multicolumn{2}{|c|}{ Kharif 2013} & \multicolumn{2}{|c|}{ Rabi 2013-14 } \\
\hline & & & $\begin{array}{l}\text { Before } \\
\text { spray }\end{array}$ & $\begin{array}{l}\text { 20d } \\
\text { after } \\
\text { spray }\end{array}$ & $\begin{array}{l}\text { Before } \\
\text { spray }\end{array}$ & $\begin{array}{l}\text { 20d } \\
\text { after } \\
\text { spray }\end{array}$ \\
\hline \multirow[t]{2}{*}{ T 1} & TAQAT 75\% WP & $500 \mathrm{~g}$ & 15.55 & 22.2 & 27.77 & 28.55 \\
\hline & $($ Captan $70 \%+$ Hexaconazole $5 \%)$ & & $(23.34)$ & $(28.11)$ & $(31.76)$ & $(32.27)$ \\
\hline \multirow[t]{2}{*}{ T 2} & TAQAT $75 \%$ WP & $750 \mathrm{~g}$ & 18.88 & 14.4 & 26.14 & 14.16 \\
\hline & $($ Captan $70 \%+$ Hexaconazole $5 \%)$ & & $(25.70)$ & $(22.30)$ & $(30.72)$ & $(21.97)$ \\
\hline \multirow[t]{2}{*}{ T 3} & Captan 50\% WP & $700 \mathrm{~g}$ & 15.55 & 28.1 & 19.62 & 27.77 \\
\hline & & & $(23.34)$ & $(32.01)$ & $(26.28)$ & $(31.76)$ \\
\hline \multirow[t]{2}{*}{$\mathrm{T} 4$} & Captan 50\% WP & $1050 \mathrm{~g}$ & 12.22 & 24.1 & 29.99 & 25.55 \\
\hline & & & $(20.44)$ & $(29.40)$ & $(33.15)$ & $(30.36)$ \\
\hline \multirow[t]{2}{*}{ T5 } & Hexaconazole 5\% SC & $500 \mathrm{ml}$ & 17.77 & 29.6 & 28.03 & 36.56 \\
\hline & & & $(24.88)$ & $(32.96)$ & $(31.95)$ & $(37.23)$ \\
\hline \multirow[t]{2}{*}{ T6 } & Hexaconazole 5\% SC & $750 \mathrm{ml}$ & 18.88 & 26.7 & 20.36 & 28.88 \\
\hline & & & $(25.70)$ & $(31.11)$ & $(26.71)$ & $(32.46)$ \\
\hline \multirow[t]{2}{*}{$\mathrm{T} 7$} & Hexaconazole $5 \%$ SC & $1000 \mathrm{ml}$ & 20.00 & 25.2 & 21.47 & 23.40 \\
\hline & & & $(26.57)$ & $(30.13)$ & $(27.56)$ & $(28.93)$ \\
\hline \multirow[t]{4}{*}{$\mathrm{T} 8$} & Control & -- & 19.99 & 36.3 & 25.88 & 46.62 \\
\hline & & & $(26.56)$ & $(37.05)$ & $(30.53)$ & $(43.03)$ \\
\hline & Co-efficient of Vari & ce $(\mathrm{CV})$ & NS & 13.9 & NS & 13.9 \\
\hline & Critical Differ & nce (CD) & NS & 4.20 & NS & 3.2 \\
\hline
\end{tabular}

Figures in the parentheses represent arcsine transformed values 
Table.3 Effect of TAQAT 75\% WP (Captan 70\% + Hexaconazole 5\%) on stem rot disease of rice

\begin{tabular}{|c|c|c|c|c|c|c|}
\hline \multirow{3}{*}{$\begin{array}{l}\text { Sl } \\
\text { No }\end{array}$} & \multirow{3}{*}{ Treatments } & \multirow{3}{*}{ Dose/l } & \multicolumn{4}{|c|}{ Stem rot Disease Severity (PDI) } \\
\hline & & & \multicolumn{2}{|c|}{ Kharif 2013} & \multicolumn{2}{|c|}{ Rabi 2013-14 } \\
\hline & & & $\begin{array}{l}\text { Before } \\
\text { spray }\end{array}$ & $\begin{array}{c}\text { 20d after } \\
\text { spray }\end{array}$ & $\begin{array}{l}\text { Before } \\
\text { spray }\end{array}$ & $\begin{array}{c}\text { 20d after } \\
\text { spray }\end{array}$ \\
\hline \multirow[t]{2}{*}{$\mathrm{T} 1$} & TAQAT 75\% WP & $500 \mathrm{~g}$ & 24.44 & 22.58 & 28.60 & 35.10 \\
\hline & $($ Captan $70 \%+$ Hexaconazole $5 \%)$ & & $(29.60)$ & $(28.35)$ & $(32.35)$ & $(36.33)$ \\
\hline \multirow[t]{2}{*}{$\mathrm{T} 2$} & TAQAT 75\% WP & $750 \mathrm{~g}$ & 17.77 & 13.7 & 15.55 & 17.49 \\
\hline & (Captan $70 \%+$ Hexaconazole $5 \%)$ & & $(24.88)$ & $(21.72)$ & $(23.24)$ & $(24.65)$ \\
\hline \multirow[t]{2}{*}{ T 3} & Captan 50\% WP & $700 \mathrm{~g}$ & 32.22 & 36.29 & 33.66 & 39.22 \\
\hline & & & $(34.57)$ & $(37.05)$ & $(35.43)$ & $(38.76)$ \\
\hline \multirow[t]{2}{*}{$\mathrm{T} 4$} & Captan 50\% WP & $1050 \mathrm{~g}$ & 35.55 & 34.44 & 30.27 & 33.88 \\
\hline & & & $(36.57)$ & $(35.94)$ & $(33.40)$ & $(35.61)$ \\
\hline \multirow[t]{2}{*}{ T5 } & Hexaconazole 5\% SC & $500 \mathrm{ml}$ & 29.99 & 35.55 & 39.77 & 42.71 \\
\hline & & & $(33.15)$ & $(36.60)$ & $(39.06)$ & $(40.80)$ \\
\hline \multirow[t]{2}{*}{ T6 } & Hexaconazole 5\% SC & $750 \mathrm{ml}$ & 30.00 & 33.0 & 27.99 & 32.10 \\
\hline & & & $(33.21)$ & $(35.06)$ & $(31.88)$ & $(34.51)$ \\
\hline \multirow[t]{2}{*}{$\mathrm{T} 7$} & Hexaconazole 5\% SC & $1000 \mathrm{ml}$ & 25.55 & 30.74 & 25.55 & 27.49 \\
\hline & & & $(30.33)$ & $(33.65)$ & $(30.33)$ & $(31.62)$ \\
\hline \multirow[t]{4}{*}{ T8 } & Control & - & 45.55 & 44.07 & 40.82 & 49.71 \\
\hline & & & $(42.42)$ & $(41.55)$ & $(39.70)$ & $(44.84)$ \\
\hline & Co-efficient $\mathrm{C}$ & nce $(\mathrm{CV})$ & NS & 13.7 & NS & 11.8 \\
\hline & Critical & nce (CD) & NS & 4.1 & NS & 4.9 \\
\hline
\end{tabular}

Figures in the parentheses represent arcsine transformed values

Table.4 Effect of TAQAT 75\% WP (Captan 70\% + Hexaconazole 5\%) on grain yield

\begin{tabular}{|c|c|c|c|c|}
\hline \multirow{2}{*}{$\begin{array}{r}\text { Sl } \\
\text { No. }\end{array}$} & \multirow[t]{2}{*}{ Treatments } & \multirow[t]{2}{*}{ Dose/l } & \multicolumn{2}{|c|}{ Yield (q/ha) } \\
\hline & & & $\begin{array}{c}\text { Kharif } \\
2013\end{array}$ & $\begin{array}{c}\text { Rabi 2013- } \\
14\end{array}$ \\
\hline $\mathrm{T} 1$ & $\begin{array}{l}\text { TAQAT } 75 \% \text { WP } \\
\text { (Captan } 70 \%+\text { Hexaconazole } \\
5 \% \text { ) }\end{array}$ & $500 \mathrm{~g}$ & 61.25 & 55.80 \\
\hline T 2 & $\begin{array}{l}\text { TAQAT } 75 \% \text { WP } \\
\text { (Captan } 70 \%+\text { Hexaconazole } \\
5 \% \text { ) }\end{array}$ & $750 \mathrm{~g}$ & 67.25 & 64.35 \\
\hline T 3 & Captan 50\% WP & $700 \mathrm{~g}$ & 52.67 & 49.23 \\
\hline $\mathrm{T} 4$ & Captan 50\% WP & $1050 \mathrm{~g}$ & 54.15 & 54.70 \\
\hline T5 & Hexaconazole 5\% SC & $500 \mathrm{ml}$ & 49.25 & 50.10 \\
\hline T6 & Hexaconazole 5\% SC & $750 \mathrm{ml}$ & 55.3 & 55.50 \\
\hline $\mathrm{T} 7$ & Hexaconazole 5\% SC & $1000 \mathrm{ml}$ & 53.3 & 58.50 \\
\hline T8 & Control & -- & 44.52 & 41.32 \\
\hline & Co-efficient of $V$ & ce (CV) & 12.25 & 13.68 \\
\hline & Critical Dif & ce (CD) & 4.59 & 3.2 \\
\hline
\end{tabular}


Previous workers reported the efficacy of Hexaconazole $5 \mathrm{SC}$ in reducing the sheath rot incidence (Vidhyasekaran and Lewin, 1987; Kindo and Tiwari, 2015) and in this present study we report the enhanced efficacy of Hexaconazole $5 \%$ in combination with Captan $70 \%$ compared to the Hexaconazole $5 \% \mathrm{SC}$ alone. In the present investigation, we have also tested the efficacy of Hexaconazole 5 SC in different doses (500, 750 and 1000 $\mathrm{ml} / \mathrm{ha}$ ) which recorded on par PDI among themselves but recorded higher PDI than TAQAT $75 \%$ WP (Captan 70\% + Hexaconazole 5\%) @ $750 \mathrm{~g} / \mathrm{ha}$ in both the season.

\section{Stem rot}

Test fungicide TAQAT 75\% WP (Captan $70 \%$ + Hexaconazole 5\%) @ 750 g/ha preformed better than the other chemicals in both the season in reducing the stem rot PDI. It recorded PDI of 13.7 and 17.49 in Kharif 2013 and Rabi 2013-14 respectively which is statistically significant over other treatments. Several fungicides in solo formulation such as Benomyl, Edifenphos, Thiophanate Methyl, Propiconozole have been reported earlier as effective in reducing stem rot disease under field condition (Singh et al., 2002; Kumar et al., 2003; Gopika et al., 2016). In this experiment, we have reported the superiority of a combination fungicide (Captan 70\% + Hexaconazole 5\%) over other solo fungicide in reducing the stem rot disease severity under field condition (Table 3) (Figs. 1 and 2).

\section{Yield}

Difference in the disease severity of sheath blight, sheath rot and stem rot diseases in different treatment was finally reflected in the grain yield. Significant increase in the grain yield in Kharif 2013 (67.25 q/ha) and Rabi 2013-14 (64.35 q/ha) was observed in the plots treated with test chemical TAQAT 75\% WP (Captan 70\% + Hexaconazole 5\%) @ 750 g/ha (67.25 q/h) (Table 4) (Figs. 1 and 2). Whereas, other fungicide treatments, recorded yield in the range of 44.52-61.25 q/ha in Kharif 2013 and 41.32-58.50 q/ha in Rabi 2013-14 (Table 4) (Figs. 1 and 2). Our results are in conformity with those of previous reports (Sood and Kapoor, 1997; Tirmali et al., 2001; Prabhu et al., 2003, Usman et al., 2009; Naik et al., 2012; Bhuvaneshwari and Raju, 2012; Bag et al., 2016; Pramesh et al., 2016 a,b) reported that fungicides application increases the yield of rice. The increased yield is mainly due to reduced disease severity of sheath blight, sheath rot and stem rot.

Combination fungicides are better compare to the other solo fungicides due to their broad range of action, lower dose and also posses lower risk of fungicide resistance development in target fungal population. In case of rice, resistance varieties for sheath blight, sheath rot and stem rot are not developed/available/ yet to the farmer. Moreover, poor bio-efficacy of the biocontrol agents under the severe epidemic condition makes the chemical control is an inevitable and ultimate means for disease management for farmers. Thus, in present situation cultural practices combined with foliar spray of fungicide is the most common practice to manage the disease and even in integrated pest management system need based application of fungicide has been recommended (Bag et al., 2016).

In conclusion, present investigation provides the field efficacy of a fungicide premixture TAQAT 75\% WP (Captan 70\%+ Hexaconazole 5\%) @ 750 g/ha for management of sheath blight, sheath rot and stem rot diseases of paddy.

\section{Acknowledgment}

Authors thankful to Director of Research, University of Agricultural Sciences, Raichur, Karnataka and Campus Head, Agricultural 
Research Station, Gangavathi for providing necessary research facilities and funding for conducting the experiment.

\section{References}

Agnihothrudu, V., 1973. Acrocylindrium oryzae Sawada - sheath rot on paddy. Kavaka 1: 69-71.

Anonymous, 2009. DRR Progress Report. Indian Council of Agricultural Research, Hyderabad, Andhra Pradesh, India.

Bag, M. K. and Saha, S., 2009. Fungitoxic effect of Nativo $75 \mathrm{wg}$ (trifloxystrobin $25 \%+$ tebuconazole $50 \%$ ) on grain discoloration (GD) disease of rice in West Bengal. Pestology. 33: 47-49.

Bag, M. K., Yadav, M. and Mukherjee, A. K., 2016. Bioefficacy of Strobilurin Based Fungicides against Rice Sheath Blight Disease. Transcriptomics. 4:128.

Bhaktavatsalam, G., Satyanarayana, K., Reddy, A. P. K. and John, V. T., 1978. Evaluation of sheath blight resistance in rice. Int. Rice Res. Newsl. 3: 9-10.

Bhuvaneswari, V. and Raju, K. S., 2012. Efficacy of New Combination Fungicide against Rice Sheath Blight Caused by Rhizoctonia solani (Kuhn). Journal of Rice Research. 5 (1 and 2).

Biswas, A. and Bag, M. K., 2010. Strobilurins in management of sheath blight disease of rice: A review. Pestology. 34: 23-26.

Bonman, J. M., Estrada, B. A., Kim, C. K., Ra, D. S. and Lee, E. J., 1991. Assessment of blast disease and yield loss in susceptible and partially resistant rice cultivars in two irrigated low land environments. Plant Disease. 75: 462-466.

Brent, K. J. and Hollomon, D. W., 1998. Fungicide Resistance: the Assessment of Risk. FRAC Monograph, 2. Crop Life International, Brussels, Belgium.
Cattaneo, A., 1876. Sullo Sclerotium oryzae nouvo parasite vegetable che ha devasto nel corrente anno molte risaje di lombardia e del Novarese. Rediconti R. Lombard., Milano. 2ser 9: 801-807.

Cintas, N. A. and Webster, R. K., 2001. Effects of Rice Straw Management on Sclerotium oryzae Inoculum, Stem Rot Severity, and Yield of Rice in California. Plant Disease. 85 (11).

Gopika, K., Jagadeeshwar, R., Rao, V. K. and Vijayalakshmi, K., 2016. Salient resarch findings on rice stem rot disease (Sclerotium oryzaecatt.) and its management. International Journal of Plant, Animal and Environmental Sciences. 6(1).

Groth, D. E. and Bond, J. A. 2006. Initiation of rice sheath blight epidemics and effectof application timing of azoxystrobin on disease incidence, severity, yield, and milling quality. Plant Disease. 90: 1073-1076.

Jackson, L. F., Webster, R. K., Wick, C. M., Bolstad, J. and Wilkerson, J. A., 1997. Chemical control of stem rot of rice in California. Phytophathology. 67:11551158.

Kandhari, J. and Gupta, R. L., 2003. Efficacy of fungicides and resistance inducing chemicals against sheath blight of rice. Journal of Mycological Research. 41: 67-69.

Karmakar, S. K., Mishra, S. K., Mohapatra, K. B. and Mishra, B., 1992. Response of rice cultivars against sheath rot disease caused by Sarocladium oryzae (Sawada) W. Games and Haeksorth, under protected and unprotected condition. Orissa J. Agric. Res. 5: 209-214.

Kindo, D. and Tiwari, P. K., 2015. Efficacy of fungicides for management of sheath rot disease in rice under field 
conditions. Plant Archives. 15 (1):119-120.

Kole, C., 2006. Cereals and millets (Vol. 1): Springer. http://dx.doi.org/10.1007/ 978-3-540-34389-9.

Kumar, A., Singh, R. and Jalali, B. L., 2003. Management of stem rot of rice with resistance inducing chemicals and fungicides. Indian Phytopathology. 56(3):266-69.

Kumar, P. M. K., Gowda, S. D. K., Rishikant, M., Kumar, K. N., Gowda, P. K. T. and Vishwanath, K., 2013. Impact of fungicides on rice production in India In: Fungicides - showcases of integrated plant disease management from around the world (open access chapter)., pp. 77-98.

Kumar, P. M. K. and Veerabhadraswamy, A. L., 2014. Appraise a combination of fungicides against blast and sheath blight diseases of paddy (Oryza sativa L.). Journal of Experimental Biology and Agricultural Sciences. 2 (1).

Naeimi, S., Okhovvat, S. M., Hedjaroude, G. A. and Khosravi, V., 2003. Sheath rot of rice in Iran. Commun. Agric. Appl. Biol. Sci. 68: 681-684.

Naik, G. R., Naik, G. B., Naik, B. T. and Naik, K. R., 2012. Fungicidal management of leaf blast disease in rice. Global Journal Bio science and Biotechnology. 1 (1): 18-21.

Ou, S. H., 1985. Rice Diseases, 2ndedn. Commonwealth Mycological Institute, Surrey.

Phookan, A. K. and Hazarika, D. K., 1992. Distribution of sheath rot (ShR) in six agroclimatic zones of Assam, India. IRRN. 17: 16.

Prabhu, A. S., Filipp, M. C. and Zimmermann, F. J. P., 2003. Cultivar response to fungicide application in relation to rice blast control, productivity and sustainability. Pesq. Agropec. Bras., Brasilia. 38:11-17.
Pramesh, D. and Guruprasad, G. S., 2014. Stem rot disease of rice: an emerging disease threatening rice production in Karnataka. In National conference on "Emerging challenges and opportunities in biotic and abiotic stress management (ECOBASM2014) during Dec 15-18 at DRR, Hyderabad.

Pramesh, D., Maruti, Muniraju, K. M., Mallikarjun, K., Guruprasad, G. S., Mahantashivayogayya, K., Reddy, B. G. M., Gowdar, S. B. and Chethana, B. S., 2016. Bio-efficacy of a Combination Fungicide against Blast and Sheath Blight Disease of Paddy. Journal of Experimental Agriculture International. 14(4): 1-8

Pramesh, D., Nataraj, K., Guruprasad, G. S., Mahantashivayogayya, K. and Reddy, B. G. M., 2016. Evaluation of a new strobilurin group of fungicide for the management of blast disease of paddy. American J. Experimental Agri. 13(5): 1-6.

Rajan, C. P. D., 1987. Estimation of yield losses due to sheath blight of rice. Indian Phytopathology. 40: 174-177.

Reddy, C. S. and Ghosh, A., 1985. Sheath rot incidence and yield losses in rice due to the joint infection of rice tungro virus and sheath rot fungus. Indian Phytopath. 38(1):165.

Roy, A. K., 1993. Sheath blight of rice in India. Indian Phytopathology. 46: $97-$ 205.

Savary, S. and Mew, T. W., 1996. Analyzing crop losses due to Rhizoctonia solani: rice sheath blight, a case study. In: Sneh B, Javaji-Hare S, Neate S, Dijst G (eds) Rhizoctonia species: taxonomy, molecular biology, ecology, pathology and disease control, Kluwer, Dordrecht, pp. 237244. 
Savary, S., Teng, P. S., Willocquet, L. and Nutter, F. W. Jr., 2006. Quantification and modeling of crop losses: a review of purposes. Annual Review of Phytopathology. 44: 89-112.

Savary, S., Willocquet, L., Elazegui, F. A., Castilla, N. and Teng, P. S., 2000. Rice pest constraints in tropical Asia: quantification and yield loss due to rice pests in a range of production situations. Plant Disease. 84: 357-369.

Seebold, K. W., Datnof, J. L. E., CorreaVictoria, F. J., Kucharek, T. A. and Suyder, G. H., 2004. Effects of Silicon and fungicides on the control of leaf and neck blast in Upland rice. Plant Disease. 88:253-258.

Singh, N. I. and Devi, R. K., 1999. Departmental Disease Survey Report, College of Agriculture, CAU, Imphal. pp. 5.

Singh, R., Kumar, A. and Jalali, B. L., 2002. Variability, predisposing factors and management of stem rot caused by Sclerotium oryzae, An Overview. Annual review of plant pathology. 1: 275-289.

Sood, G. K. and Kapoor, A. S., 1997. Efficacy of new fungicides in the management of rice blast. Plant Disease Research. 12:140-142.

Teng, P. S., Torries, C. Q., Nuque, F. L. and Calvero, S. B., 1990. Current Knowledge on crop losses in tropical rice. In: IRRI (ed) Crop loss assessment in rice. International Rice Research Institute, Los Banos. pp. 3954.

Tirmali, A. M., Latake, S. B. and Bendra, N. J., 2001. Evaluation of new fungicides for control of blast disease of rice. Journal of Maharashtra Agricultural University. 26:197-198.

Usman, G. M., Wakil, W. Sahi, S. T. and Saleemil, Y., 2009. Influence of various fungicides on the management of rice blast disease. Mycopathology. 7: 29-34

Venkateswarlu, B. and Venkateswarlu, D., 2004. Efficacy of certain fungicides for the management of rice sheath rot Sarocladium oryzae (Sawada). Pl. Protec. Bull. 56(3/4): 1-6.

Vidhyasekaran, P. and Lewin, H. D., 1987. Time of spraying to control sheath rot (ShR). IRRN. 12(6): 21-22.

Webster, R. K., Wick, C. M., Brandon, D. M., Hall, D. H. and Bolstad, J., 1981. Epidemiology of stem rot disease of rice: effects of burning vs. soil incorporation of rice residue. Hilgardia. 49(3):1-12.

Zhang, C. Q., Liu, Y. H., Ma, X, Y., Feng, Z. and Ma, Z. H., 2009. Characterization of sensitivity of Rhizoctonia solani, causing rice sheath blight to mepronil and boscalid. Crop Protection. 28: 381-386.

\section{How to cite this article:}

Pramesh, D., Saddamhusen Alase, K.M. Muniraju and Kirana Kumara, M. 2017. A Combination Fungicide for the Management of Sheath Blight, Sheath Rot and Stem Rot Diseases of Paddy. Int.J.Curr.Microbiol.App.Sci. 6(9): 3500-3509. doi: https://doi.org/10.20546/ijcmas.2017.609.430 